\title{
Koinonía cristã: pressuposto hermenêutico da comunidade primitiva dos Atos dos Apóstolos
}

\author{
Christian koinonia: hermeneutical presupposition of
} the primitive community of the Acts of the Apostles

\section{Luiz Alexandre Solano Rossi, Alfredo Rafael Belinato Barreto*}

Pontifícia Universidade Católica do Paraná (PUCPR), Curitiba, PR, Brasil

\section{Resumo}

O presente artigo visa demonstrar que a identidade da comunidade cristã primitiva é fator indispensável à compreensão dos primeiros movimentos realizados pelo cristianismo. 0 livro dos Atos dos Apóstolos retrata a dinâmica desenvolvida pela fé cristã no intuito de afirmar-se no contexto do mundo judaico-pagão do séc. I. Os sumários maiores apresentados por Lucas (At 2,42-47; 4,32-35; 5,12-16), fornecem elementos-chave que descrevem a convivência dos primeiros cristãos, e revelam sua identidade. Dentre eles a koinonía emerge como background de um projeto mais amplo de vivência e moderação das relações comunitárias. Assim sendo, a importância do conceito para a reflexão acerca da comunidade primitiva pode ser inferida do lugar central que o mesmo ocupa na obra lucana. Além disso, a abrangência de seu significado, no conjunto literário dos

LASR: PhD, e-mail: luizalexandrerossi@yahoo.com.br

ARBB: Doutorando em Teologia, e-mail: alfredobelinato@yahoo.com.br

Rev. Pistis Prax., Teol. Pastor., Curitiba, v. 9, n. 3, 740-759, set./dez. 2017 
Atos dos Apóstolos, corrobora seu caráter fundamental na constituição e consolidação dos traços primordiais da vivência comunitária dos primeiros cristãos. Deste modo, a koinonía impõe-se como pressuposto hermenêutico indispensável à compreensão dos primeiros dias do cristianismo retratados pela obra de Lucas.

Palavras-chave: Cristianismo. Koinonía. Identidade. Comunidade.

\section{Abstract}

The present article aims to demonstrate that the identity of the primitive Christian community is essential to the comprehension of the first movement fulfilled by Christianity. The book of the Acts of the Apostles portrays the dynamics developed by the Christian faith in order to assert itself in the context of the Jewish-pagan world of the first century. The larger summaries presented by Lucas (Act 2,42-47; 4,32-35; 5,12-16) provide key elements that describe the coexistence of the first Christians, and disclose their identity. Among them the koinonía comes up as a backdrop of a broader project of experience and moderation of the community relationship. Therefore, the importance of the concept in regarding to the primitive community can be inferred from the aforesaid central place that occupies the Lucan job. Moreover, the scope of its meaning in the literary set of the Acts of the Apostles confirms its fundamental nature in the constitution and consolidation of the primary traces of the first Christians community living. Thus, the koinonía imposes itself as essential hermeneutical presupposition to the comprehension of the first days of Christianity described by Lucas' job.

Keywords: Christianity. Koinonía. Identity. Community.

\section{Introdução}

A comunidade cristã primitiva sempre despertou a atenção dos críticos da religião, dos estudiosos da história da Igreja e particularmente dos exegetas do Novo Testamento. A organização comunitária é lugar primordial e originário da gênese e desenvolvimento das expressões de fé apresentadas pelo cristianismo antigo. Assim sendo, emerge como aspecto 
imprescindível à análise dos primeiros movimentos realizados pela Igreja em contexto jerosolimitano e pagão. Em última instância, o perfil comunitário cristão primitivo permite tocar na identidade dos primeiros cristãos, que constitui, por sua vez, a autocompreensão que eles desenvolveram de si enquanto adeptos da nova fé anunciada por Cristo.

O passo a dar, portanto, é identificar nos elementos recorrentes apresentados pelos sumários maiores dos Atos dos Apóstolos (2,42-47; 4,32-35; 5,12-16), as categorias descritivas fundamentais da comunidade cristã primitiva. A proposta é inferir princípios-chave que norteiem a leitura da vida dos primeiros cristãos, a partir das informações fornecidas por Lucas nos sobreditos sumários, em conexão com outros textos do Novo Testamento e dados recolhidos da pesquisa histórico-teológica acerca da obra lucana. Nesse ínterim, particular atenção será dada ao conceito de koinonía, que embora utilizado apenas uma vez (At 2,42), emerge como zona de convergência dos diversos outros aspectos que compõem o quadro de análise.

O foco sobre a koinonía deve-se ao fato de nela ser possível situar o pressuposto hermenêutico fundamental à definição e compreensão da identidade dos primeiros cristãos. Por isso, primeiramente será importante apontar em linhas gerais o lugar que o conceito ocupa no livro dos Atos dos Apóstolos, considerando também sua caracterização histórica e teológica própria. Após ter ressaltado alguns aspectos no que se refere à definição, apresentar-se-á a análise dos possíveis significados da koinonía cristã na obra lucana. Cumpre notar que essa reflexão será construída a partir da divisão feita por Philippe Ménoud (1952) na obra La vie de l'Église naissante. Note-se igualmente, que o presente estudo não objetiva esgotar a temática, mas apontar elementos-chave acerca da mesma.

\section{O lugar da koinonía nos Atos dos Apóstolos}

O livro dos Atos dos Apóstolos apresenta o quadro de conjunto dos primeiros movimentos realizados pelo Cristianismo. As tradições recolhidas e elencadas por Lucas explicitam o elo existente entre a Igreja de Jerusalém, e aquelas originadas da expansão ao mundo pagão. Com efeito, a abertura ao paganismo sinaliza o universalismo missionário subjacente à própria gênese da fé cristã. $O$ autor é cuidadoso nesse sentido, 
pois estabelece de forma crescente o mandato missionário de Jesus aos Apóstolos, no momento que imediatamente precede a ascensão (cf. At 1,8). Portanto, Jerusalém converte-se em ponto de partida do Evangelho; Judeia, Samaria e os confins da terra passam a ser imagem do destino abrangente da nova fé ${ }^{\text {. }}$

Conforme observa Echegaray (2002, p. 12), do ponto de vista geográfico o livro dos Atos pode ser dividido em duas partes ${ }^{2}$. Desta divisão Jerusalém emerge como origem da pregação; Roma, por sua vez, sinaliza o ponto de culminância do vasto trabalho evangelizador realizado na costa oriental do mar Mediterrâneo. No bloco formado pelos capítulos 1-12, particularmente referentes à atividade de Pedro, Lucas situa as primeiras descrições da comunidade primitiva em contexto jerosolimitano.

Echegaray (2002, p. 12) ressalta que neste bloco "descrevem-se os costumes da comunidade cristã e especialmente as ideias básicas de suas crenças, assim como as estruturas argumentativas das mesmas, sobretudo através das orações, ou dos conselhos e discursos dos apóstolos" (tradução nossa). Assim, é neste nível que a koinonía, aplicada à vida cristã, adquire status de pressuposto hermenêutico à compreensão da identidade dos primeiros cristãos.

Os capítulos 13-28 compõem o segundo bloco de tradições, centrado na figura do apóstolo Paulo, e na difusão e consolidação do cristianismo em contexto pagão. Apoiado nessa ambivalência geográfica, Echegaray (2002, p. 12) conclui que, "na realidade, a cidade de Roma, junto com a de Jerusalém, resultam ser a chave para entender a estrutura e o sentido dos Atos dos Apóstolos" (tradução nossa). Entretanto, a análise da koinonía

1 Segundo Boudou (1957, p. 10-11), a descrição da missão apostólica feita pelo autor dos Atos evidencia que esta não está limitada a Israel. Os Apóstolos devem cruzar as fronteiras de Jerusalém e entrar em contato com os confins do mundo, cujo expoente máximo é Roma, a capital do Império. Apoiando-se nas observações de Boudou é possivel classificar At 1,8 como expressão típica do universalismo que impulsionará o empreendimento missionário cristão. Deve-se se observar também que no encontro com as diversas culturas a koinonía emergiu como fator unificador.

2 A este respeito Monasterio e Carmona (2000, p. 282) afirmam que "Atos 1,8 quer apresentar os grandes passos no caminho testemunhal da Igreja primitiva, os critérios da geografia, o material e sumários permitem distinguir dois grandes blocos na descrição desse caminho; um, no qual predomina a atividade na Palestina sob a direção de Pedro, os Doze e a Igreja de Jerusalém (1-12); e outro, em que predomina a atividade fora da Palestina e neste Paulo é o protagonista (13-28)". 
cristã revela algo mais abrangente nesta relação histórica e teologicamente estabelecida entre Jerusalém e Roma no livro dos Atos dos Apóstolos. Em linhas gerais, cumpre notar que o ideal comunitário oriundo da primeira comunidade jerosolimitana converteu-se em elemento distintivo e normativo para o cristianismo antigo em seus mais diversos matizes.

Nesse sentido, o método empregado por Lucas, a fim de caracterizar a identidade dos primeiros cristãos, consiste na interpolação de sumários em sua narração ${ }^{3}$. Dupont $(1974$, p. 41) salienta que "a narração dos Atos é frequentemente interrompida por observações gerais, breves apanhados sintéticos que se assemelham a pontos de revezamentos, marcos na marcha da história". Tais interpolações podem ser concebidas como elemento de articulação entre fatos determinantes na história da comunidade primitiva.

Segundo Fabris (1991, p. 20) são distinguíveis três sumários maiores $^{4}$ relativos à vida e à organização da primeira comunidade de Jerusalém. Neles estão condensados e idealizados alguns dados tradicionais sobre a primavera da Igreja. At 2,42-47; 4,32-35; 5,12-16 traçam o perfil da comunidade jerosolimitana, e lança as bases do ideal comunitário a ser adotado pelo cristianismo subsequente. Não obstante, a diversidade linguística e redacional, a recorrência de determinados elementos evidenciam a importância dos mesmos à própria autocompreensão da comunidade primitiva.

Possivelmente, a koinonía, embora o termo seja empregado por Lucas uma única vez (At 2,42), é o ambiente vital sobre o qual se desenvolvem os demais elementos destacados. Emerge como o prisma sob o

3 A pesquisa exegética não é unânime acerca da função dos sumários nos Atos, bem como em relação à historicidade e à intenção do autor ao inserir os mesmos na obra. Dupont (1974, p. 41) elenca algumas hipóteses e as consequências por elas suscitadas à compreensão dos sumários. Klaus Berger (1998, p. 299) prefere definir os blocos narrativos convencionalmente denominados "sumários" com o conceito de "relato básico". Berger argumenta que a denominação "sumário" está marcadamente orientada pelas cenas elaboradas, ao passo que "relatos básicos" insere os textos em outra perspectiva. Com efeito, "os relatos básicos não são abreviações marginais; eles transmitem a plenitude decisiva da ação. Eles formam a base da narração, da qual as cenas específicas se levantam, como acima do mar se erguem as cristas de espuma". Fabris (1991, p. 20) concebe os sumários como "pausas mais ou menos amplas, que ajudam a tomar pé da situação depois de alguns acontecimentos decisivos e preparam o leitor para os desenvolvimentos subseqüentes".

4 Fabris (1991, p. 21) divide os sumários em maiores e menores. A função dos sumários menores é indicar ao leitor a conclusão de um bloco narrativo maior ou o início de uma nova seção. São linhas-mestras à interpretação não só em nível geográfico e cronológico, mas também teológico e espiritual. Exemplos de sumários menores são: At 6,7; 9,31; 11,21; 12,24.

Rev. Pistis Prax., Teol. Pastor., Curitiba, v. 9, n. 3, 740-759, set./dez. 2017 
qual estes devem ser interpretados, no intuito de se traçar as linhas-mestras do ideal comunitário cristão primitivo. O esforço é por delinear as dimensões intrínsecas à compreensão da comunidade cristã dos Atos, mediante a análise sincrônica dos sumários descritivos. Para isso a reta compreensão do conceito koinonía é fundamental.

\section{Proposta de definição}

De acordo com a tese de Dupont (1974, p. 505), uma primeira definição da koinonía foi dada pelo próprio Lucas, ao escrever que "todos os que tinham abraçado a fé reuniam-se e punham tudo em comum: vendiam suas propriedades e bens, e dividiam-nos entre todos, segundo as necessidades de cada um" (2,44-45). Essa concepção recorre em 4,32 onde se lê que "a multidão dos que haviam crido era um só coração e uma só alma. Ninguém considerava exclusivamente seu o que possuía, mas tudo entre eles era comum".

At 4,34-35 reflete o ideal já apresentado em 2,45: "Não havia entre eles necessitado algum. De fato, os que possuíam terrenos ou casas, vendendo-os, traziam os valores das vendas e os depunham aos pés dos apóstolos. Distribuía-se então, a cada um, segundo sua necessidade".

Lucas é cuidadoso ao esboçar a convivência dos primeiros cristãos. Por isso, procura fundamentar a veracidade da descrição sumária por meio de exemplos concretos. Um deles encontra-se na generosidade de Barnabé, que vendendo seu campo, levou o dinheiro e depositou aos pés dos apóstolos (cf. 4,36-37). Resulta evidente que, a partir da prática comum da koinonía chega-se ao nível que poderia ser denominado "comunhão material" ou "comunhão de bens".

Por outro lado, ao abrir o primeiro sumário em 2,42, Lucas elenca quatro níveis que, de certa forma compilam dimensões diversas de significação da koinonía para a comunidade primitiva dos Atos. "Eles mostravam-se assíduos $^{5}$ ao ensinamento dos apóstolos, à comunhão fraterna, à fração do pão

5 A Bíblia de Jerusalém traduz o imperfeito do indicativo $\pi \rho \circ \sigma \kappa \alpha \rho \tau \varepsilon \rho \circ \cup v \tau \varepsilon \varsigma$ do verbo $\pi \rho \circ \sigma-\chi \alpha \rho \tau \varepsilon \rho \varepsilon \omega$ (perseverar) por "mostravam-se assíduos". Tradução mais fiel seria "perseveravam"; considerando que as quatro dimensões da koinonía apresentadas por Lucas emergem como consequência da perseverança na fé acolhida mediante a pregação de Pedro (cf. At 2,14-41). 
e às orações". Esta perspectiva lucana corrobora a tese segundo a qual na koinonía reside o fundamento da autocompreensão da comunidade primitiva.

O fato de a comunhão não estar reduzida ao âmbito da justiça, e ao consequente estabelecimento de um modo de vida igualitário, indica que "estas perseveranças descrevem suficientemente toda a vida da Igreja” (MÉNOUD, 1952, p. 10, tradução nossa). Ou seja, a perseverança nestes quatro níveis, sintetiza o ideal comunitário cristão retratado pelo livro de Atos, e ao mesmo tempo, aponta a perspectiva abrangente que a koinonía adquirira no mesmo. Nesse sentido, Dupont (1974, p. 519) observa:

A $\chi 01 v \omega v i \alpha$, à qual, segundo At 2,42, os primeiros cristãos se mostravam assíduos, esclarece-se pelo que 2,44 e 4,32 referem da maneira de terem eles "tudo em comum". Esta $\chi 01 v \omega v i \alpha$ não reside simplesmente no fato de juntos participarem $(\mu \varepsilon \tau \varepsilon \chi \omega)$ dos mesmos bens, ou na solidariedade resultante desta participação comum; adquire uma tonalidade ativa, a saber, os cristãos tiram as consequiências dessa solidariedade, praticando com perseverança a $\chi 0 ı v \omega v i \alpha$, colocando tudo o que possuíam em comum. Sua atitude é o oposto do egoísmo individualista do "cada qual para si" ${ }^{\text {; }}$ é o cuidado pelo outro (cf. Fl 2,4; 1 Cor 10,24.33; 13,5; Rm 15,2), a exemplo de Cristo que, "sendo rico, fez-se pobre por nosso amor (2Cor 8,9). Esta $\chi 0 ı v \omega v ı \alpha$ consiste mais especialmente em pôr tudo à disposição dos necessitados, sem nada reservar para si só; assim aparece como a manifestação concreta e o sinal sensível da união dos corações e das almas.

É necessário assinalar, portanto, que, na compreensão apresentada por Lucas acerca da vida da comunidade primitiva, a significação da koinonía não é unívoca. Com efeito, diversos autores procuraram estabelecer abrangente e objetivamente as possíveis acepções subjacentes ao conceito ${ }^{7}$. Deter-se-á aqui sobre a divisão apresentada por Phillippe Ménoud, na obra La vie de l'Église naissante. De acordo com o autor, a koinonía cristã presente nos Atos dos Apóstolos pode ser traduzida em quatro níveis referentes à:

6 A fraude de Ananias e Safira relatada em At 5,1-11 chama a atenção para 0 caráter paradoxal da vivência cristã. Ainda que a koinonía fosse 0 ambiente fundamental das relações novas cultivadas na comunidade primitiva, o realismo lucano não exclui a tensão entre o ideal comunitário e o individualismo egoísta também presente em seus membros. Significativo é o fato de Lucas situar a fraude do casal entre o exemplo edificante da generosidade de Barnabé (cf. 4,36-37) e o terceiro sumário descritivo da comunidade (cf. 5,12-16).

7 Dupont (1974, p. 504) apresenta uma síntese das principais divisões.

Rev. Pistis Prax., Teol. Pastor., Curitiba, v. 9, n. 3, 740-759, set./dez. 2017 
1) Comunhão espiritual entre si e com os apóstolos;

2) Comunhão material, pondo em comum os bens temporais;

3) Comunhão eucarística, unindo os fiéis a Cristo por meio do sacramento;

4) Comunhão eclesiástica; unidade dos crentes manifestada na coleta em prol da Igreja de Jerusalém (cf. Rm 12,13).

A elaboração de Ménoud propõe novamente a interpretação da koinonía como critério fundamental à compreensão da identidade dos primeiros cristãos. Entretanto, cumpre notar que, ao sistematizar as significações do conceito, o autor interpreta os sumários progressivamente. Assim sendo, os fatos que envolvem a caminhada da Igreja e são subsequentemente relatados no livro dos Atos, aparecem como pressupostos hermenêuticos à ideia de comunhão retratada nos sumários. Alguns pormenores destes níveis serão objeto da análise seguinte.

\section{Níveis de significação da koinonía cristã}

A pluralidade significativa do conceito de koinonía, identificável no uso feito por Lucas ao definir os traços primordiais da comunidade cristã primitiva, resumem, de certa forma, o status social e antropológico desta comunidade. A koinonía é categoria fundamental à interpretação da identidade comunitária dos cristãos primitivos. É, ao mesmo tempo, o aspecto distintivo da comunidade, a expressão e a realização concreta da união entre os crentes ${ }^{8}$.

Em linha de continuidade, Atos enuncia o conteúdo constitutivo do ser cristão nos primeiros dias da Igreja; é o paradigma vinculativo entre seus membros. Assim sendo, o rompimento de tal vínculo passava a significar o

8 Ao iniciar o artigo L'union entre les premiers chrétiens dans les Actes des Apôtres Dupont (1969, p. 33) afirma que "a situação da comunidade cristã se define por uma série de relações: com o Cristo e com 0 Espírito Santo, com a comunidade judaica e com o mundo pagão. Há também aquelas que uma fé comum criou entre os cristãos. Em relação a uns aos outros, que se encontram em uma 'comunhão', que pode, aliás tomar formas diversas. A exposição que empreendi deve examinar o que o texto dos Atos diz desta comunhão na qual a união dos crentes encontra sua expressão e realização concreta". 
abandono e o malogro da própria vida comunitária ${ }^{9}$. Isso se pode inferir do episódio relativo à conduta de Ananias e Safira em At 5,1-11.

A centralidade da koinonía na configuração da identidade cristã deve-se, particularmente, ao fato de ser ela o princípio aglutinador dos diversos níveis componentes da vida dos crentes. Por isso, Phillipe Ménoud (1952, p. 22-34) divide a koinonía cristã em quatro níveis de significação, conforme já dito anteriormente.

\section{Comunhão Espiritual}

Apoiando-se em At 2,42, é possível inferir a comunhão espiritual como primeiro nível de significação da koinonía cristã. Com efeito, Lucas inaugura o sumário indicando a perseverança dos crentes no ensinamento dos apóstolos e na comunhão fraterna. A este respeito, Ménoud (1952, p. 11) julga necessário estabelecer distinção entre "pregação" e "ensinamento". Acerca dos crentes descritos por Lucas, afirma que

a pregação missionária está atrás deles, é uma etapa passada de sua existência, da qual não mais necessitam. É o ensinamento que lhes é necessário. É a este ensinamento que devem permanecer fielmente unidos agora e por toda a duração de sua vida cristã (tradução nossa).

A comunhão espiritual diz respeito, portanto, à ressonância da palavra anunciada no seio da comunidade destinatária. Cumpre notar que Lucas é cuidadoso em relatar com detalhes o conteúdo da pregação apostólica através dos discursos, que tem como objeto fundamental a exposição do querigma ${ }^{10}$. Colocam-se assim as dimensões espirituais e normativas sobre as quais os crentes devem perseverar em nível de fé e de ação.

9 A fraude de Ananias e Safira (cf. At 5,1-11) aparece novamente como exemplo típico deste rompimento da comunhão. Portanto, a morte do casal (cf. At 5,5.10) pode ser interpretada não somente sob o aspecto biológico, mas também como imagem da comunhão rompida pelo egoísmo.

10 Tucídides foi quem introduziu a técnica dos discursos na historiografia clássica e Lucas a adotou ao redigir os Atos. Segundo Echegaray (2002, p. 23) “Lucas parece tê-la empregado nos Atos dos Apóstolos, de forma que tanto os discursos de Pedro, como de Estevão e Paulo, onde com freqüência é sintetizada a história da salvação, vinculada à de Israel, seriam reconstruções de Lucas de acordo com a mentalidade, opiniões, formas de pensamento e expressões da Igreja primitiva" (tradução nossa). 
Nesse processo, estão imbricadas a pregação apostólica e a comunidade receptora nela perseverante. Resulta evidente que, em perspectiva lucana, a perseverança no ensinamento dos apóstolos acentua o vínculo de comunhão com o colégio apostólico enquanto grupo de testemunhas autorizadas da mensagem cristã. Este vínculo de união é o ponto de partida e a instância de conservação da comunhão espiritual entre os crentes.

Sob o viés da estrutura literária desenvolvida por Lucas nos referidos sumários maiores, a comunhão entre os fiéis e os apóstolos mediante a perseverança no ensinamento apostólico emerge como tema transversal. Este poderia ser esquematicamente apresentado da seguinte forma:

1) "Eles mostravam-se assíduos ao ensinamento dos apóstolos" (At 2,42);

2) "Com grande poder os apóstolos davam testemunho da ressurreição do Senhor" (At 4,33);

3) "Pelas mãos dos apóstolos faziam-se numerosos sinais e prodígios no meio do povo" (At 5,12).

Percebe-se então que, segundo a abordagem lucana, a atividade apostólica está diretamente orientada para a comunidade; a ela ligada mediante comunhão espiritual. A imagem dos apóstolos retratada nos respectivos sumários aparece estritamente relacionada com três âmbitos fundamentais na constituição da Igreja primitiva: koinonía, martyría e diakonía.

A comunhão dos crentes com a Palavra anunciada concretiza-se na perseverança no ensinamento $(\delta 1 \delta \alpha \chi \eta=$ didaché $)$ apostólico. O testemunho $(\mu \alpha \rho \tau u \rho 1 \alpha=$ martyría) dos apóstolos acerca da ressurreição do Senhor remete ao conteúdo da pregação ouvida e crida pela comunidade. Por isso, está novamente em pauta o vínculo de unidade entre todos os crentes; os apóstolos testemunham a mesma fé que ensinam e que por sua vez deve ser também testemunhada por aqueles que a acolhem.

Enfim, os sinais $(\sigma \eta \mu \varepsilon 1 \alpha)$ realizados junto ao povo sinalizam a confirmação do ensinamento e do testemunho. A generosidade de Barnabé (cf. At 4,36-37) confirma a descrição da comunidade feita em At 2,42-47; 4,32-37. Os sinais e prodígios são apresentados como corroboração da 
autenticidade da pregação apostólica, particularmente sob a forma de serviço aos necessitados ${ }^{11}$.

Por conseguinte, em nível espiritual, a koinonía cristã caracteriza-se primariamente pelo compromisso de conservar a fé recebida dos apóstolos, e que deve ser vivenciada em comunidade. Aqueles que acreditaram através da pregação, e nela perseveraram na comunhão, eram "um só coração e uma só alma. Ninguém considerava exclusivamente seu o que possuía, mas tudo entre eles era comum" (At 4,32).

Nesse versículo estão salientes dois traços da convivência comunitária dos primeiros cristãos, que permitem a transição do sentido espiritual da koinonía para sua significação material. A correspondência entre estes traços permite o estabelecimento de uma relação consequencial entre o sentido espiritual e o material da koinonía cristã. Segundo Dupont (1974, p. 514), a ambivalência de valores sinaliza que "a unidade espiritual existente entre os fiéis acarreta a prática da comunhão no plano dos bens materiais".

Por isso, o autor conclui que "a unidade das almas é ao mesmo tempo causa e efeito de uma atitude pela qual cada um considera seus bens como sendo comum a todos" (1974, p. 519). O nível espiritual emerge como motivação e ambiente vital da dimensão material da koinonía, conforme exposto a seguir.

\section{A comunhão de bens}

É possível estabelecer um limite deveras próximo entre o sentido espiritual e material da koinonía, segundo a impostação dada pelos Atos dos Apóstolos. A “comunhão de bens" é, de per se, expressão e manifestação concreta das ações realizadas no interior da comunidade primitiva, no intuito de pôr em prática o vínculo primário da comunhão fraterna (cf. At 2,42). Segundo Ménoud (1952, p. 23), este nível de significação da koinonía pode ser definido como

11 Os milagres realizados pelos apóstolos podem ser compreendidos como elemento de continuidade entre 0 ministério de Jesus Cristo e a missão de seus seguidores. Possivelmente, é sob este prisma que os milagres aparecem como autentificação da mensagem apostólica. Acerca disso, observe-se que Lucas estabelece elementos similares entre os relatos de milagres narrados no Evangelho e nos Atos dos Apóstolos: Lc 5,17-26/ At 9,32-35; Lc 8,49-56/At 36-42.

Rev. Pistis Prax., Teol. Pastor., Curitiba, v. 9, n. 3, 740-759, set./dez. 2017 
A comunhão dos bens necessários à existência terrestre, comunhão à qual os crentes são dedicados mais que os outros homens. "Não vos esqueçais da beneficência e da comunhão, porque são estes os sacrifícios que agradam a Deus" (Hb 13,16). Sem empregar a palavra comunhão, o autor dos Atos informa que os fiéis de Jerusalém colocavam tudo em comum (At 2,44; 4,32). - É o sentido material (tradução nossa).

Sob este prisma é possível compreender Atos 2,44-45, onde se lê que "todos os que tinham abraçado a fé reuniam-se e punham tudo em comum ( $\varepsilon \nmid \chi \circ \nu \alpha \pi \alpha \nu \tau \alpha \kappa o \iota v \alpha$ ): vendiam suas propriedades e bens, e dividiam-nos entre todos, segundo as necessidades de cada um". De forma similar esta mesma aplicação da comunhão é descrita por Lucas em 4,32.34-35:

A multidão dos que haviam crido era um só coração e uma só alma. Ninguém considerava exclusivamente seu o que possuía, mas tudo entre eles era comum ( $\eta v \alpha v \tau o ı \varsigma \alpha \pi \alpha v \tau \alpha \kappa o เ v \alpha)$. [...] Não havia entre eles necessitado algum. De fato, os que possuíam terrenos ou casas, vendendoos, traziam os valores das vendas e dos depunham aos pés dos apóstolos. Distribuía-se então, a cada um, segundo sua necessidade.

Observe-se que saliente é o emprego feito por Lucas do adjetivo

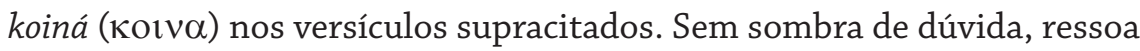
aqui o contexto amplo da koinonía como aspecto distintivo da comunidade, através do qual ela mesma se autocompreendeu. É válido ressaltar que o fato de os cristãos colocarem tudo em comum corresponde, em certa medida, ao elemento de continuidade entre o sentido espiritual e material da koinonía. Deste modo, a comunhão de bens aliada à comunhão espiritual são aspectos complementares a conferir estabilidade e autenticidade à mensagem cristã.

Em contrapartida, é o elemento que manifesta a índole histórica da fé cristã, ou seja, o espaço no qual o âmbito teológico-doutrinário aterrissa na prática, configurando assim a identidade comunitária no contexto religioso plural dos séculos I-II. Consequentemente, a comunhão de bens, relida à luz 
das tradições posteriores à redação dos Atos dos Apóstolos, permite inferir o impacto sociológico desencadeado pelo cristianismo no mundo antigo ${ }^{12}$.

Assim sendo, a articulação entre sentido espiritual e material da koinonía cristã informa que à comunhão subjetiva das almas e do coração (cf. At 4,32) corresponde a unidade objetiva concretizada na partilha dos bens.

Apoiando-se nessas considerações, é possível identificar a intenção de Lucas em asseverar o equilíbrio entre a mudança de mentalidade oportunizada pela fé abraçada e o testemunho da mesma na vida prática. De acordo com Ménoud (1952, p. 26), o emprego feito pela comunidade primitiva da comunhão recapitula e sinaliza tal equilíbrio. Diz o autor que

Uma comunhão que se limitasse ao domínio espiritual operaria um divórcio que o cristianismo repudia. Ela separaria a palavra da ação. Não estaria mais em harmonia com a vontade divina, para a qual dizer e fazer são um. Definitivamente ela perderia aquilo mesmo que pretendia conservar: o vínculo espiritual com Deus. Por outro lado, uma comunhão limitada ao domínio material não seria mais que uma série de atos de liberalidade. Obedeceria a um ideal humanitário, mas perderia todo fundamento especificamente cristão. O cristianismo conhece uma única comunhão, que é a fé de ordem espiritual e de ordem temporal (tradução nossa).

Essa asserção é elucidativa, pois assegura que, na koinonía retratada por Lucas, união espiritual e comunhão de bens não são dimensões estanques de um mesmo conceito. A relação dialética existente entre esses dois níveis fundamentais é garantida pelo vínculo de causalidade e dependência subjacente a ambos.

Desta aproximação provém a coerência e a congruência da fé com a prática comunitária, manifestada também na celebração eucarística, expressão cúltica da koinonía, objeto a ser analisado adiante.

12 Discussão interessante sobre o impacto sociológico do Cristianismo no mundo antigo é apresentada por STARK, Rodney. 0 crescimento do cristianismo. Um sociólogo reconsidera a história. São Paulo, Paulinas, 2006. 


\section{A comunhão eucarística}

Não sem relação com os dois significados da koinonía cristã analisados anteriormente, emerge o sentido eucarístico da comunhão entre os crentes. Com efeito, numa primeira interpretação a aplicação do adjetivo "eucarístico" parece anacrônica, visto sugerir a leitura deste nível da koinonía através dos conceitos teológicos desenvolvidos posteriormente com relação ao vocabulário ritual e sacramental da Igreja.

Por outro lado, observação mais cuidadosa identifica a inegável intenção eucarística de Lucas ao situar na sequência das "perseveranças" de At 2,42 a "fração do pão", e retomando-a em 2,46 ao afirmar que "dia após dia, unânimes, mostravam-se assíduos no Templo e partiam o pão pelas casas, tomando o alimento com alegria e simplicidade de coração".

A abertura da análise requer atenção primária sobre a localização da "fração do pão"13 no conjunto das perseveranças típicas da comunidade cristã. Lucas a insere entre a "comunhão fraterna" e as "orações", ou seja, duas dimensões tipicamente constitutivas, e em consequência disso, descritivas do ideal comunitário dos primeiros cristãos em sua vertente litúrgico-celebrativa. Assim sendo, o timbre eucarístico da afirmação aparece reforçado, sobretudo, pelo fato de muito cedo a expressão "fração do pão" ter sido empregada primariamente em referência à celebração eucarística ${ }^{14}$.

Acerca da relação entre comunhão e eucaristia na comunidade primitiva, Ménoud (1952, p. 10) ressalta que "a unidade e a coesão que a Igreja revela praticando a comunhão, ela encontra sempre de novo seu modelo e princípio celebrando, na fração do pão, o rito instituído pelo próprio

13 É importante salientar que a expressão "fração do pão" só aparece três vezes nos Atos dos Apóstolos: $2,42.46 ; 20,7$. Jungmann $(2009$, p. 28$)$ observa que “neste uso da palavra 'fração do pão' estamos diante de um modo de expressão novo, cristão, alheio, tanto à literatura judaica, quanto à clássica. Este novo termo deve corresponder a um novo objeto, o pão sagrado da comunidade cristã".

14 No verbete "Eucaristia", segundo o Dicionário de patrística e de antiguidades cristãs (BERARDINO, 2002, p. 527) se lê que "nos primeiros séculos cristãos, a fractio panis faz parte do culto, com a pregação dos apóstolos, a comunhão e as orações. Ela aparece conexa com a ceia tomada pelo Ressurreto, donde a sua dominante de alegria, e com a última ceia, pelo que sua celebração é 'anúncio da morte do Senhor, até que ele venha' (1Cor 11,26)". Em Didaqué 14,1 aos cristãos é prescrito: "Reúnam-se no dia do Senhor para partir o pão e agradecer.... A expressão recorre na Carta aos efésios de Inácio de Antioquia 20,1: "partindo o mesmo pão, que é remédio de imortalidade...". 
Senhor, a fim de se unir a seus fiéis e os unir a ele" (tradução nossa). Deste modo, a fração do pão emerge como característica particular da fé abraçada e ao mesmo tempo como caminho, por meio do qual a comunidade dos crentes poderá atingir sua meta escatológica.

O horizonte eucarístico que envolve a expressão "fração do pão" nos Atos dos Apóstolos é confirmado pela celebração realizada por Paulo em Trôade, em cuja ocasião se deu a ressurreição do jovem Êutico ${ }^{15}$. At 20,7 afirma que "no primeiro dia da semana, estando nós reunidos para a fração do pão, Paulo entretinha-se com eles”.

Daqui é possível presumir o caráter doméstico deste ato comunitário, já aludido em 2,46: "dia após dia, unânimes, mostravam-se assíduos no Templo e partiam o pão pelas casas, tomando o alimento com alegria”. Possivelmente, é este caráter doméstico que confere à fração do pão o coeso significado aqui analisado, enquanto vínculo de união que manifesta a koinonía cristã.

A relação entre frequência ao Templo e a fração do pão pelas casas é elucidativa no tangente à vida litúrgica da comunidade, que, por sua vez, estava diretamente orientada para a convivência comunitária. A união eucarística da congregação dos crentes é imagem da koinonía mais ampla e profunda que embasa toda a vida da comunidade primitiva. Acerca deste aspecto, Kürzinger (1968, p. 83), chama a atenção; "notemos como o autor denomina 'a fração do pão pelas casas', distinguindo-a notavelmente da participação cotidiana nas cerimônias judaicas no templo e acrescentando à parte a informação de que 'tomavam a refeição em comum"'.

Constata-se, portanto, a possibilidade de se estabelecer o sentido eucarístico da koinonía cristã enquanto nível de significado. Essa abordagem destes elementos apresentados nos Atos dos Apóstolos torna-se mais consistente quando enriquecida com a prática das comunidades paulinas, cujo testemunho encontra-se registrado nas cartas legadas pelo Apóstolo. Todavia, essa relação próxima entre as diferentes comunidades acena para o último nível de significação da koinonía. Trata-se do sentido eclesiástico

15 Taylor (2010, p. 45) vê na narração desta celebração em Trôade (cf. At 20,7-12) na qual está envolvida a morte e a ressurreição de Êutico uma espécie de conto eucarístico, no qual os acontecimentos estão orientados para o significado que a eucaristia possuía para o cristianismo primitivo. 
ou eclesiológico, expressão da unidade subjacente à compreensão que a comunidade teve de si mesma.

\section{A comunhão eclesiástica}

Retomando elementos dos três significados anteriormente analisados, emerge o sentido eclesiástico da koinonía cristã como síntese e concretização desta dimensão constitutiva da comunidade primitiva. Este nível de significado representa, igualmente, aspecto importante da compreensão que a Igreja concebe de si mesma, enquanto unidade paradigmática e elemento de coesão na pluralidade das comunidades.

Segundo Ménoud (1952, p. 23), o fato que esboça a dimensão eclesiástica da koinonía cristã é "a coleta organizada pelo apóstolo Paulo nas Igrejas pagãs em favor dos fiéis de Jerusalém ${ }^{16}$; revela a união de todos os crentes em Cristo" (tradução nossa).

A interpretação deste fato sob o prisma da comunhão requer outra observação acerca da natureza da koinonía cristã. A esse respeito Dupont (1974, p. 517) destaca que

a koinonía cristã se baseia essencialmente no fato de que os fiéis gozam dos mesmos bens divinos; são esses bens compartilhados por todos juntos, que asseguram o fundamento objetivo da comunhão fraterna. Uma comunhão tão profunda conduz naturalmente à obrigação de partilhar bens temporais com os que deles carecem.

16 Segundo At 11,27-30 a coleta foi motivada pela fome que grassou na Palestina durante o reinado do imperador Cláudio (41-54 d.C). Eusébio de Cesaréia em sua História Eclesiástica noticia o acontecimento nestes termos: “Caio, porém, não exerceu o poder por quatro anos. Sucedeu-lhe o imperador Cláudio. Sob este último, uma fome devastou a terra inteira. Até os historiadores alheios a nossa doutrina transmitiram essa notícia em suas obras. Assim se cumpriu a predição do profeta Ágabo, que consta nos Atos dos Apóstolos, a respeito da fome vindoura, sobre a terra" $(8,1)$. Wikenhauser $(1973$, p. 199) observa que "fontes profanas informam que, em diversas ocasiões durante 0 reinado de Cláudio, várias províncias foram flageladas pela fome. Sabe-se com segurança que Grécia o foi no ano 49, e Roma no ano 50. Enquanto na Judeia, consta por Josefo que sobre os procuradores Fado e Tibério Alexandre (44-48) sobreveio uma fome espantosa, e que algo tem a ver com 0 ano sabático, durante o qual não era permitido aos judeus cultivar os campos; 0 ano sabático caiu precisamente do outono de 47 ao outono de 48. Parece que na Palestina a carestia culminou no ano 49". 
Apoiado nesta compreensão, o apóstolo Paulo infere argumentos no intuito de esclarecer aos fiéis pagãos o sentido da coleta destinada à Igreja jerosolimitana. Ao noticiar a participação da Macedônia e da Acaia no auxílio aos cristãos pobres de Jerusalém (cf. Rm 15,25-26), Paulo justifica o fato afirmando que "houve por bem, é verdade, mas eles lhes eram devedores: porque se as nações participaram de seus bens espirituais, devem, por sua vez, servi-los nas coisas temporais".

Indubitavelmente, os bens espirituais nos quais os gentios tomaram parte através da pregação apostólica e a adesão à fé remetem à origem judaica de Jesus. Com efeito, ao falar do lugar dos judeus na economia da salvação, o Apóstolo não hesita em dizer que deles descende Cristo segundo a carne (cf. Rm 9,5).

Do significado dado por Paulo à coleta realizada em prol da Igreja de Jerusalém, pode-se inferir a natureza da comunhão eclesiástica. Não se trata somente da união em âmbito jurídico, doutrinal ou jurisdicional. Já no cristianismo primitivo, aparecem os primeiros delineamentos dos vínculos que haveriam de definir aquilo que posteriormente ficou conhecido por "catolicidade" da Igreja ${ }^{17}$.

Note-se assim, que a base fundamental da união entre as Igrejas é a dimensão espiritual, já analisada anteriormente. O ponto de partida e de conservação da comunhão é a união na fé em Cristo transmitida pela pregação apostólica. Outra observação de Dupont (1969, p. 909) é significativa a esse respeito. Diz o autor que

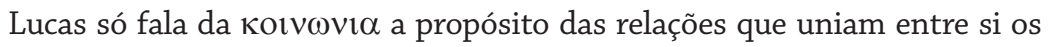
crentes da comunidade de Jerusalém. Nós podemos já pensar que o que é

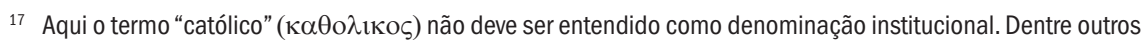
significados que a palavra apresentou já na antiguidade está a referência à universalidade da Igreja. Segundo Peretto (apud BERARDINO, 2002, p. 275) "no grego clássico, a palavra católico já possuía o significado de universal". Nos primórdios do séc. II Inácio de Antioquia empregou o conceito em sentido cristão: "Onde aparece o bispo, aí esteja a multidão, do mesmo modo que onde está Jesus Cristo, aí está a Igreja católica" (Ad Esm. 8,2). Também o relato do martírio de Policarpo de Esmirna sugere similar uso do termo: "Quando por fim terminou de rezar, lembrou-se de todos aqueles que tinha conhecido, pequenos e grandes, ilustres ou obscuros, e de toda a Igreja católica espalhada por toda a terra" $(8,1)$. Com efeito, estes usos primitivos do termo permitem igualmente inferir que a universalidade da Igreja era compreendida sempre em referência à comunhão situada em sua base.

Rev. Pistis Prax., Teol. Pastor., Curitiba, v. 9, n. 3, 740-759, set./dez. 2017 
verdade em nível de uma comunidade local deve encontrar também sua aplicação em nível mais largo da comunhão entre as diferentes comunidades.

A esse respeito cumpre observar o papel proeminente da comunidade jerosolimitana nos primeiros dias da Igreja. Nela se dá o Pentecostes e dela parte o ideal missionário cristão (cf. At 2). Eloquente testemunho dessa união entre as Igrejas consiste na assembleia dos apóstolos em Jerusalém (cf. At 15), acerca da necessidade ou não da circuncisão para os convertidos oriundos do paganismo.

Lucas assim descreve a acolhida de Paulo, Barnabé e dos outros que subiram com eles a Jerusalém (cf. At 15,2): “chegados a Jerusalém, foram acolhidos pela Igreja, pelos apóstolos e anciãos, e relataram tudo o que Deus fizera por meio deles" (At 15,4).

Portanto, é possível identificar no sentido eclesiástico da comunhão entre os crentes o fator que conferiu identidade à Igreja. Fator que favoreceu o estabelecimento de vínculos entre os convertidos, de forma a constituir um grupo coeso em meio às culturas circundantes, e ao culto mistérico desgastado do séc. I, porém, largamente disseminado.

À guisa de síntese, o modo de expressão da comunhão eclesiástica na comunidade primitiva apresenta-se como forma de conservação da perseverança discutida anteriormente. "Eram um só coração e uma só alma” (cf. At 4,32), embora se referindo à particular comunidade jerosolimitana, aponta para o projeto posto à totalidade das Igrejas cristãs que a partir dela haveriam de se constituir ainda no séc. I.

\section{Considerações finais}

Os elementos apresentados acima permitem concluir, primeiramente, o lugar estratégico reservado por Lucas à koinonía no livro dos Atos. Embora o conceito apareça apenas uma vez (At 2,42), o ideal por ele evocado permeia e norteia o conjunto dos acontecimentos narrados. É possível compreender o significado da koinonía sob a forma de um movimento crescente, que parte da restrita comunidade jerosolimitana dos convertidos em Pentecostes, para a teologia universalista da comunhão eclesial esboçada já na coleta feita por Paulo em favor da empobrecida Igreja de Jerusalém. 
Por conseguinte, identifica-se a abrangência da koinonía enquanto aspecto descritivo da identidade dos primeiros cristãos. De certa forma é possível estabelecê-la como princípio de individuação no tecido das relações comunitárias cristãs. Acerca disso, cumpre notar que é precisamente a koinonía ferida que se impõe como critério de julgamento ao comportamento desonesto de Ananias e Safira. Sem sombra de dúvida, a "mentira" ao Espírito Santo de que foram acusados é precedida pela descrição do egoísmo do casal (cf. At 5,1-11), que consiste no rompimento da comunhão identificada entre os membros da comunidade.

Esta abrangência do conceito corresponde à sua importância para a vida da comunidade primitiva. Deste modo, a análise entre a koinonía e os primeiros cristãos deve pressupor o caráter central que a mesma desempenhou na organização interna da comunidade. Nela, a primeira geração cristã encontrou seu elemento de coesão, e ao mesmo tempo de distinção, em relação às outras religiões disseminadas no Império Romano no contexto do séc. I. A koinonía sinaliza ainda o âmbito privilegiado à resolução dos conflitos comunitários, tendo presente que, em sua descrição dos primeiros dias da Igreja, Lucas deixa entrever os momentos de tensão e paradoxo na convivência dos cristãos (ex. At 5,1-11; 15).

Enfim, cumpre notar que a koinonía não se reduz a simples status conceitual, estabelecendo-se como background à constituição da identidade cristã. É sob este prisma que ela se torna pressuposto hermenêutico à compreensão da identidade dos primeiros cristãos. Assim sendo, todo esforço ou tentativa de compreensão ou análise do protocristianismo lucano, e daquele que se seguiu à primeira geração cristã, toca irrenunciavelmente na koinonía vivenciada pela comunidade primitiva e delineada pelos Atos dos Apóstolos.

\section{Referências}

ANTIOQUIA, I. Carta aos efésios. São Paulo: Paulus, 2008a.

BERARDINO, A (org.). Dicionário de patrística e de antiguidades cristãs. São Paulo: Paulus, 2002.

BERGER, K. As formas literárias do Novo Testamento. São Paulo: Loyola, 1998. 
BOUDOU, A. Atti degli Apostoli. Roma: Editrice Studium, 1957.

CESARÉIA, E. História eclesiástica. São Paulo: Paulus, 2008.

DIDAQUÉ. São Paulo: Paulus, 2008.

DUPONT, J. Estudos sobre os Atos dos Apóstolos. São Paulo: Paulinas, 1974.

DUPONT, J. L'union entre les premiers chrétiens dans les Actes des Apôtres. Nouvelle revue théologique, Paris, v. 91, n. 9, p. 897-915, nov. 1969.

ECHEGARAY, J. G. Los Hechos de los Apóstoles y el mundo romano. Navarra: Editorial Verbo Divino, 2002.

FABRIS, R. Atos dos Apóstolos. São Paulo: Loyola, 1991.

JUNGMANN, J. A. Missarum sollemnia. São Paulo: Paulus, 2009.

KÜRZINGER, J. Commenti spirituali del Nuovo Testamento. Atti degli Apostoli. Roma: Città Nuova, 1968.

MARTÍRIO de São Policarpo, bispo de Esmirna. São Paulo: Paulus, 2008.

MÉNOUD, P.-H. La vie de l’Église naissante. Paris: Neuchâtel, 1952.

MONASTERIO, R. A.; CARMONA, A. R. Evangelhos sinóticos e Atos dos Apóstolos. São Paulo: Ave Maria, 2000.

STARK, R. O crescimento do cristianismo. Um sociólogo reconsidera a história. São Paulo, Paulinas, 2006.

TAYLOR, J. As origens do cristianismo. São Paulo: Paulinas, 2010.

WIKENHAUSER, A. Los Hechos de los apostoles. Barcelona: Herder, 1973.

Recebido: 09/06/2016

Received: 06/09/2016

Aprovado: 08/09/2017

Approved: 09/08/2017 